\title{
THE NEUTRAL ASPECT IN EASTERN DAN ${ }^{1}$
}

Valentin Vydrin

INALC0; LLACAN; St. Petersburg State University;

Institut universitaire de France

vydrine@gmail.com

\begin{abstract}
The paper deals with a default aspectual construction in Eastern Dan (<Southern Mande < Mande < Niger-Congo). This construction may express different aspectual meanings, depending on the lexical semantics of a verb, on the presence or absence of a direct object or an adverbial, and on the pragmatic status of the argument: habitual, stative, counter-factual, progressive, imperfect, resultative or perfect, and completive meanings are all attested. At the same time, Eastern Dan has specialized verbal constructions for most of these aspectual meanings. In the paper, conditions for the realization of different aspectual meanings are discussed. A hypothesis on the origin of this construction is suggested.
\end{abstract}

Key words: verbal aspect, Aktionsart, habitual, perfect, imperfect, Dan, Mande

Wū sūu gbàn yr̆ slòs bīr wuì gú. 'The body of the elephant contains all other kinds of meat.'

(a Dan proverb)

\section{Basic information about Eastern Dan}

Eastern Dan is a group of dialects of the Dan macrolanguage (South Mande < Southeastern Mande < Mande < Niger-Congo) spoken in Western Côte d'Ivoire by some 650,000 people; the total number of Dan speakers (in Côte d'Ivoire, Liberia and, marginally, in Guinea) is more than 1,600,000. In this study, Eastern Dan is represented by the Gwectaa dialect which was selected in the 1980s as the standard variety for the written norm of Eastern Dan. All the data for this study were collected by the author in the course of regular field trips to Côte d'Ivoire carried out since 2001 .

${ }^{1}$ This paper is a revised English version of (Vydrin 2010). 
Eastern Dan is a 5-level tone language (ä extra-high, $\mathrm{xH}$; $a$ high, $\mathrm{H}$; $\bar{a}$ mid, M; à low, L; à extra-low, $\mathrm{xL}$ ), there are also 3 falling tones, of which only $\mathrm{H}-\mathrm{xL}$ (designated by a circumflex, $\hat{a}$ ) is relatively frequent. ${ }^{2}$ The basic word order is rigid: in a clause with a verbal predicate it is (S) Aux (O) V (X). ${ }^{3}$ The subject is indexed on the Aux and is very often absent; the absence of a direct object renders the verbal construction intransitive.

\section{The TAM system of Eastern Dan}

In Eastern Dan, Aux cumulatively expresses person and number of the subject, and also TAM and polarity meanings. There are several series of Aux forms (in the Mandeist tradition, they are called "predicative markers"), each series is named after its basic function, although some of them may fulfill other functions as well. ${ }^{4}$ At the same time, TAM can be marked by verbal inflexion (suffixes or tonal modifications), although verbs appear in their lexically basic form in certain TAM constructions, in which case Aux remains the sole element expressing TAM and polarity.

The verbal construction representing the main topic of interest of this paper can be regarded as the default with respect to its aspectual semantics. However, from the point of view of form, this construction cannot be considered a default: its formal markers are the existential Aux

${ }^{2}$ This paper uses the 2018 orthography for Eastern Dan. In this orthrography, absence of a tonal mark on a vowel means that the tone is identical to the preceding tone (e.g. bāa /bāā/ 'cassava'); $d h$ and $b h$ stand for implosive consonants /d/ and /b/; vocalic nasality is designated by the letter $\mathrm{n}$ following the vowels of a foot (e.g. kwàan for /kwã̀à// 'to steal'); $u, \gamma, \wedge$ stand for back unrounded vowels; œ is an open labialized vowel, and $æ$ is a front open vowel.

${ }^{3} \mathrm{~S}$ for the subject, $\mathrm{O}$ for the direct object, $\mathrm{X}$ for an oblique (adverbial, postpositional phrase, etc.), $\mathrm{V}$ for the verbal predicate, Aux for the predicative marker or bifunctional auxiliary.

${ }^{4}$ In fact, certain series can also appear in non-verbal clauses in the function of a non-verbal copula. Such series (existential, conjoint and imperfective negative) are referred to as "bifunctional auxiliaries". 
$\operatorname{series}^{5}$ and $\mathrm{xL}$ grammatical tone on the verb, e.g. bān 'to rain' $\rightarrow$ bàn 'to rain \NEUT' (in other words, tonal classes of verbs are neutralized in this contexts, see numerous examples below). In what follows, I refer to this construction as the "neutral aspect construction".

Before entering into detail on the grammatical semantics of the neutral aspect, let us first introduce the other basic aspectual constructions of Eastern Dan (constructions encoding modal meanings are not presented here) ${ }^{6}$

The Perfect is marked by the perfect Aux series, and the verb keeps its lexical tone.

(1) a. Yà dhín zü.

3SG.PRF child wash

'She has washed the child.'

The Durative is marked by the existential Aux series and the verb (with lexical tone) adds the suffix $-s i n$.

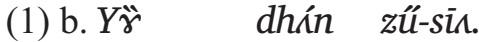

3SG.EXI child wash-DUR

'She is washing the child.'

The Resultative requires the existential Aux series and the gerund of the lexical verb (the verbal stem with the clitic -suï), followed by the comitative/instrumental postposition ká.
(1) c. $Y \ddot{\gamma}$
dhín zü-süu
ká.
3SG.EXI child wash-GER with
'She has washed a/the child.'

The Prospective requires the prospective Aux series; the verb appears in its lexical form.

${ }^{5}$ The existential Aux series, if compared with the other series from a formal point of view, can be regarded as the most primitive, inasmuch as no segmental or tonal element can be singled out which could be interpreted as a carrier of the TAM semantics, see Vydrin (2006: 355-363, 405-408).

${ }^{6}$ For more detail on TAM in Eastern Dan, see Vydrin (2017: 495-504). 


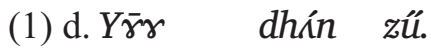 \\ 3sG.PROS child wash}

'She is going to wash the child.'

The Future is formed by an auxiliary verb dhó (whose original meaning is 'to go') in the neutral aspect followed by the infinitive of the lexical verb (the infinitive marker is an $\mathrm{xL}$ tone suffixed to the verbal stem producing a falling contour; it is designated here by an apostrophe).
(1) e. $Y \ddot{\gamma}$
dhö
dhín zü-'.
3SG.EXI golNEUT child wash-INF
'She will wash the child.'

The Retrospective construction is derived from the neutral aspect construction through insertion of the operator $k \bar{n}$ after the Aux. ${ }^{7}$

\section{(1) f. $Y \ddot{\gamma} \quad k \bar{n} \quad d h i ́ n$ zù. \\ 3SG.EXI RETR child wash/NEUT \\ 'She washed the child.' (once upon a time)}

The label 'retrospective' should be used for this construction only with reservations, because, in reality, the construction does not necessarily express retrospective meaning or the meaning of cancelled result. It may express a recent past and designate an action which retains some actuality at the moment of speech (2), cf. (Makeeva 2018) on the semantics of an analogous construction in the closely related language Kla-Dan.

\begin{tabular}{|c|c|c|c|c|c|}
\hline$Y \ddot{\gamma}$ & $k \bar{n}$ & dhüınn & bhūun, & $k^{\prime \prime} \mathcal{E}$ & yíi \\
\hline $\begin{array}{l}\text { 3SG.EXI } \\
\text { kpän }\end{array}$ & $\begin{array}{l}\text { RETR } \\
\text { à }\end{array}$ & $\begin{array}{c}\text { walk\NEUT } \\
\text { bhä. }\end{array}$ & there & & 3SG.PFV.NEG \\
\hline see & 3sG.NSBJ & $\mathrm{J} \quad$ on & & & \\
\hline
\end{tabular}

${ }^{7} k \bar{n}$ is idiosyncratic, it is the only lexeme in Eastern Dan that can appear in this syntactic slot. It can be said that the word class of operators in this language is represented by this single lexeme. 
In this study I deal only with the affirmative segment of the TAM system of Eastern Dan. In the central part of the system polarity is strongly asymmetric, and the distribution of the aspect-temporal meanings in the negative construction follows a different logic.

Worthy of special mention is the Conjoint construction marked by a specialized conjoint Aux series (bifunctional Aux) and by a tonal morpheme on the verb (the tone of the verb is lowered, according to a rather complex pattern). This construction functions as an analogue of the neutral aspect construction in certain syntactic contexts (relative clause; narrative; a clause preceded by a focalized NP, etc.), see Makeeva (2010) on this construction in Kla-Dan.

\section{Semantics of the neutral aspect construction}

The neutral aspect construction can express the following aspectual meanings (which will be illustrated in what follows):

- habitual $^{8}$,

- stative,

- unreal condition in a counter-factual construction,

- progressive,

- imperfect (for an action that was being performed in the past but was not necessarily completed),

- resultative/perfect,

- completive (for an action that was performed over a certain span of time).

It turns out that the neutral aspect is capable of bearing very different (if not diametrically opposed) aspectual meanings. And it may compete with other constructions which are specialized in these meanings

${ }^{8}$ In this study, I do not distinguish between varieties of habitual meaning, such as generic vs. habitual, cf. Dahl (1995: 420-424), i.e. between the potential and the iterative habitual. For the study of semantic oppositions relevant for the aspectual system of Eastern Dan these nuances seem to be rather unimportant, at least at the present stage. 
(the progressive, the resultative/perfect, and to some extent the completive). ${ }^{9}$

In order to determine the factors that influence the choice of the meaning of the neutral aspect construction, I made a list of the verbs attested in the Eastern Dan dictionary (Vydrine \& Kességbeu 2008) and added to this list some verbs absent from the published version. Each verb in each of its senses (i.e. 305 verbal lexemes) ${ }^{10}$ was tested in the neutral aspect construction for the abovementioned aspectual meanings. The testing was carried out through elicitation with my principal consultant Kességbeu Mongnan, and it was recursive: as soon as new typical contexts for aspectual meanings emerged, the list of verbs was checked again from the very beginning. As a result, the list of verbs has been checked at least three times, and it can be assumed that, despite some inevitable omissions, the principal trends have been detected. ${ }^{11}$

${ }^{9}$ Therefore, the Dan verbal system mismatches with the cross-linguistic "Verbal Core System" model of Stassen (1997: 267) which should necessarily consist of imperfective and perfective (in aspect-oriented languages) or past and non-past (in tense-oriented languages).

${ }^{10}$ It should be specified that in this study the basic unit is taken to be a single lexical sense of a verb (rather than a verbal lexeme with all its senses): different senses of a verb can have individual sets of characteristics, and the various senses of one verb can differ as much as senses of different verbal lexemes. Following the Semantic School of Moscow (see Apresjan 2005: 4), senses of a polysemic lexeme are named here "lexemes". In my list, there were 305 lexemes of this kind. In what follows, "homonymous lexemes" (i.e. different senses of polysemous verbs) will be

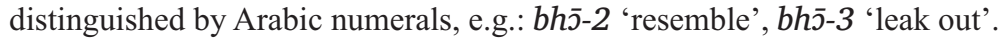

${ }^{11}$ I worked with one highly experienced and qualified consultant 7 hours a day for 11 or 12 weeks. I do not believe that recruiting more consultants (who would most probably be less qualified) would produce significantly different and more reliable results.

Usually, the study of a corpus of natural texts is suggested as an alternative to elicitation. It is evident however that such a corpus would need to be very large (preferably on the order of hundreds of millions of tokens), and the Eastern Dan corpus available at present (see http://cormand.huma-num.fr/dan/index.html) contains less than 500,000 tokens. 
The main factors relevant for the aspectual meanings of verbs in the neutral aspect construction are the following. Primarily, the lexical semantics of the verb, and more precisely its Aktionsart. Secondly, the presence or absence of obliques or dependent adverbial clauses. Thirdly, the pragmatic status (marked by the definite article, deictic element or focus marker ${ }^{12}$ ) of the verbal arguments, especially of the direct object. Cf., in particular, (3a, b; 4a, b; 5a, b).
(3) a. $Y \ddot{\gamma}$
dhüu pè
gbēy.
3SG.EXI tree saw $\backslash$ NEUT
night
'He saws tree(s) by night.' (habitual)
b. $Y \ddot{\gamma}$
dhú
bha
$p \ddot{\varepsilon}$
gbēj.
3SG.EXI
tree ART
saw $\backslash$ NEUT
night
'He sawed the tree by night.' (completive)

(4) a. Wo

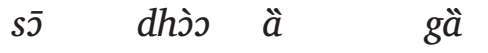

3PL.EXI cloth ART 3SG.NSBJ look\NEUT so.that

wó à dhó.

3SG.SBJV 3SG.NSBJ buy

'They are inspecting the cloth in order to buy it.' (progressive)

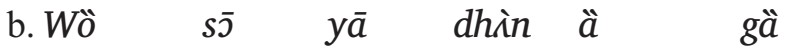

3PL.EXI cloth that FOC 3SG.NSBJ look\NEUT

$k \bar{\gamma}$ wó à dho .

so.that 3SG.JNT 3SG.NSBJ buy $\backslash$ JNT

'It is this cloth that they have watched in order to buy it.' (resultative/ perfect) ${ }^{13}$

(5) a. $Y \ddot{\gamma}$

bhlün bhā à

klöo

yāandhïr.

3SG.EXI rice ART 3SG.NSBJ thresh $\backslash$ NEUT yesterday

'She threshed the rice yesterday.' (completive)

12 In Dan, definite and focalized NPs are represented as relativized ones, for which reasons they are often followed by a resumptive 3 person pronoun.

${ }^{13}$ It should also be taken into account that in (4a) the verbal construction in the second clause is subjunctive, and in (4b), conjoint. 


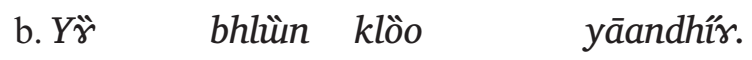

3SG.EXI rice threshlNeut yesterday

'She threshed rice yesterday (and, most probably, the job was not finished).' (imperfect).

It is not rare for a single sentence containing a neutral aspect construction to allow more than one interpretation, as in (6).
(6) $Y \ddot{\gamma}$
$b \bar{a} a$
$b h \bar{a} \quad \grave{a}$
wò
yāandhír.
3SG.EXI cassava ART 3SG.NSBJ extract/NEUT yesterday

a. 'He was digging the cassava yesterday.' (imperfect: the action was not accomplished)

b. 'He dug the cassava yesterday.' (completive: the action was accomplished) $\begin{array}{lllllll}\text { (7) } Y \ddot{\gamma} & \text { slï̀ } & \bar{\gamma} & \text { gú } & \text { kótä sősdhü yĩ } & \text { gú. } \\ \text { 3SG.EXI } & \text { turn\NEUT } & \text { REFL.SG in time five } & \text { sleeping in }\end{array}$

a. 'He has turned over five times while sleeping.' (perfect)

b. 'He turns over five times while sleeping.' (habitual)

Some verbs seem to be unable to appear in the neutral aspect construction. These include several reduplicated verbs: gblāägblāä 'yell',

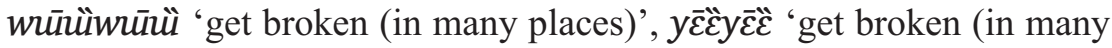
places)', a few preverbated verbs: yő-bhō 'take revenge', zò-bðั 'recollect', tä-sēë 'feel sick'; and a small number of other verbs: só 'spread' (become omnipresent), fleksn '(of a baby) pinch breast (during nursing)'.

\section{Conditions for realization of the aspectual meanings of the neutral aspect}

\subsection{Habitual}

This meaning of the neutral aspect construction can be regarded as basic. The habitual reading is usually preferred in the minimal context (when obliques are absent, and the patientive argument has no determiner), as in (8); cf. (9), where a determiner is present. 


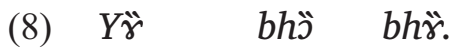

3SG.EXI pig eat \NEUT

'He eats pig.' (pig is not his totemic animal; he is not Muslim)

(9)

$\begin{array}{llllll}Y \dddot{\gamma} & \text { bhángglōo } & \text { kpồ } & \text { dhìn à } & \text { bh ̈r. } \\ \text { 3SG.EXI } & \text { mango } & \text { unripe } & \text { FOC } & \text { 3SG.NSBJ } & \text { eatlNEUT }\end{array}$

'He has eaten an unripe mango.' (resultative: ... and now he has stomach ache)

Quite often, the habitual reading turns to be an alternative to another reading, as in (7). In fact, most verbs that appear in the neutral aspect construction with habitual meaning may express other aspectual meanings as well. I have found that in the neutral aspect construction less than $10 \%$ of the verbs in my list have habitual meaning only: būn 'rear (a child)', $b h \bar{a}$ 'fructify', $b h \bar{\jmath}-2$ 'resemble', $b h \bar{\jmath}-3$ 'leak', $d h \bar{i}$ 'yield well',

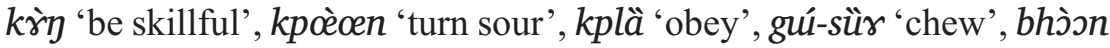

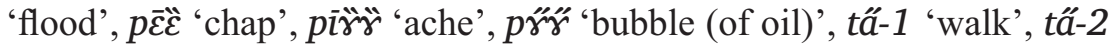

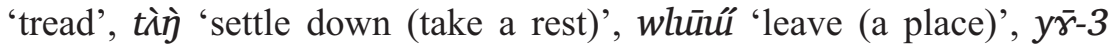

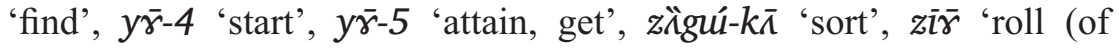
a vehicle)', ż̀̀े 'stutter', zūu-2 'begin'.

As we can see, these verbs do not form a semantically homogeneous group: among them we find dynamic and static, telic and atelic verbs.

\subsection{Stative meaning}

This meaning is realized on a restricted set of lexically stative verbs: slòo 'suffice', bhòon 'be able', kón 'be astonished', bj̄-2 'leak (of a receptacle)'. We find in the same group some verbs describing bodily postures: gblîîdhūn 'lie prone', dójindhūn 'stand', tán 'lean'. For the latter two verbs, a stative reading is available alongside the resultative one:

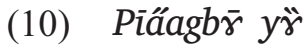
tàn
kó-báị
gú kŕr
Piagbeu 3sG.EXI lean $\backslash$ NEUT house-wall in in.order.3sG.JNT
$\bar{\gamma}$
těe-dhín bhá
$p \bar{a}$.
REFL.SG air-DIM other fill

a. 'Piagbeu leans against the house wall in order to take a rest.'

b. 'Piagbeu has leaned against the house wall in order to take a rest.' 
The habitual and stative meanings, taken together, turn out to be acceptable to the quasi-totality of the verbs of my list. I have found only one exception, tūün 'shake' (at the same time, this verb can be used in the neutral aspect construction in the progressive and imperfective meanings).

\subsection{Irreal condition in a counter-factual construction}

Realization of this aspectual meaning is possible in a sentence containing the particle of unreal condition dhún (which in other contexts expresses the meaning 'already') which can appear indifferently either in the apodosis or in protasis.
(11) $Y \ddot{\gamma}$
$b \grave{\varepsilon} d h \varepsilon_{\varepsilon} \quad b h \bar{a}$
$\dddot{a}$
bhǜn
dhún,
3SG.EXI
drug ART
yáa

gūn $y \bar{r} \bar{\gamma}$
3SG.NSBJ drinklNEUT already
3SG.IPFV.NEG be.PST 3sG.PROS die
'If he had drank this drug, he wouldn't die.'

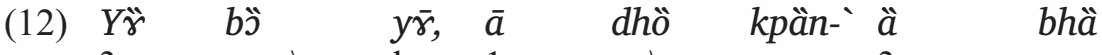
3SG.EXI pass\NeUT here $1 \mathrm{sG}$.EXI golNEUT see-INF 3 SG.NSBJ on
dhún.
already
'If he had passed here, I would see him.'

This meaning is attested for almost every verb in the list; my consultant failed to produce it for 16 lexemes only, i.e. for about $5 \%$ of the total number.

\subsection{Progressive}

The progressive reading is often an alternative to the habitual or resultative/perfect.
$(13)$
Y
3SG.EXI REFL.SG move.slowlylNEUT REFL.SG self eye.COM
a. 'He is deliberately advancing slowly.' (progressive)
b. 'He deliberately advances slowly.' (habitual) 


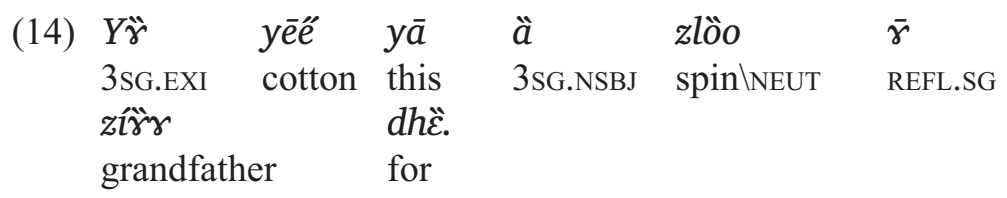

a. 'She is spinning this cotton for her grandfather.' (progressive)

b. 'She has spun this cotton for her grandfather.' (resultative/perfect)

One of the most typical contexts where the progressive meaning of the neutral aspect construction is realized (and where no alternative readings are possible, with some rare exceptions) is in a main clause governing a dependent clause of goal introduced by the conjunction

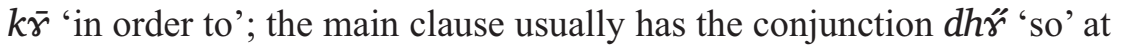
the end.
(15) $Y \ddot{\gamma}$
sír
dhùu
$d h \ddot{\gamma} \quad k \bar{\gamma}$
tế
3SG.EXI fire put.outlNEUT
so in.order wind
yá
dhó dhó-` à
klààn-dhün ká.
3 SG.PROH go
go-INF 3SG.NSBJ
spark-PL
with
'He is putting out the fire (right now), so that the wind won't spread the sparks.'

In this context only verbs expressing intentional actions can appear. The intentional character of the action seems to be an important prerequisite for realization of the progressive meaning in the neutral aspect construction, although exceptions to this rule can be found, e.g. (16).
(16)
Y'-gā
$y \bar{a} \quad y \ddot{\gamma}$
bhæ̈r
water-bone
quickly
'It seems to me that this river is drying up quickly.'

Another factor relevant to realization of the progressive meaning is the verb's Aktionsart: the progressive is not (or is barely) compatible with telic and punctual verbs. Most of these verbs cannot express the 
progressive in the neutral aspect construction (zür 'strike', zūn 'reach', $z \bar{\Lambda}$ 'kill', etc.); however, they can express a multiplicative meaning.

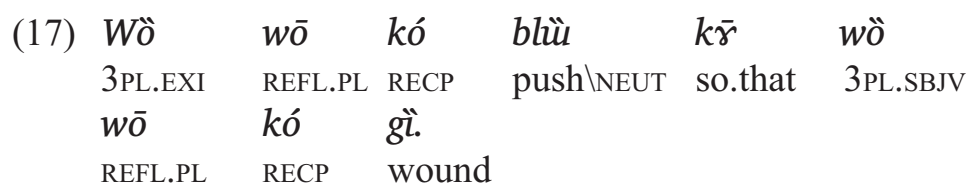

'They are pushing each other in order to wound each other.'

The influence of the referential status of the direct object on the realization of the progressive meaning seems to be weak.

The intersection of all these conditions delimits the framework of the progressive meaning of the neutral aspect construction. These are tendencies, rather than strict rules: there are verbs which seem to comply with all the abovementioned conditions, but still do not realize the progressive meaning. We are presumably dealing here with lexical restrictions.

The neutral aspect construction in its progressive meaning can be replaced by a durative construction (with verbal suffix -sĩ ), without any semantic difference. The -sin-durative can be derived from any verb, unlike the "neutral-aspect progressive", which my consultant was able to derive from 133 lexemes only (out of 305).

Even for those verbal lexemes which can display the progressive meaning in the neutral aspect construction, it was sometimes not easy to generate appropriate phrasal examples, and very special contexts were required; by contrast, the -sin-durative could be derived for the same verbs and meanings without any limitation.

\subsection{Grammatical meaning of the imperfect}

The imperfect meaning has been verified mainly in the perdurative context ("an action is being performed over a given span of time"). According to the initial hypothesis, in the presence of a temporal circumstantial designating a timespan, the perdurative and the completive (taken together with the perfect/resultative) meanings should be in complementary 
distribution: the perdurative meaning should be proper to verbs with processual, multiplicative and punctive lexical semantics (in this case, punctive verbs should display the multiplicative meaning), and the completive/perfect/resultative meaning should be proper to telic verbs. The main question concerns verbs with processual ingressive semantics.

In its main outlines this hypothesis has been confirmed. As for processual ingressive verbs, both completive (sometimes even resultative/ perfect) and imperfect interpretations have proved to be acceptable.

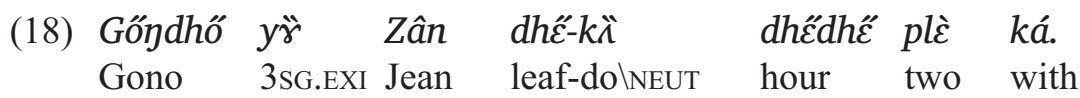

a. 'Gono healed Jean for two hours.' (the result is unknown)

b. 'Gono healed Jean in two hours.' (and Jean is now in good health)

The two aspectual interpretations can be distinguished formally through indication of the pragmatic status of the direct object. This is preferable (or even necessary) when the direct object is expressed by anything other than a proper noun or relational noun. If the direct object is indefinite, the imperfect reading of the situation is realized (19a), and if it is definite, the completive reading is preferred (19b).
(19) a

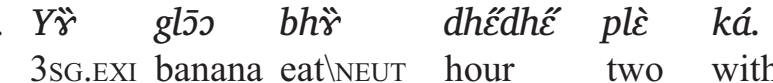
'He ate bananas for two hours.'
(19) b. Y Y
3SG.EXI banana ART-3SG.NSBJ eatlNEUT hour two with
'He ate the bananas in two hours.'

There are also some other contexts where the imperfect meaning can be realized:

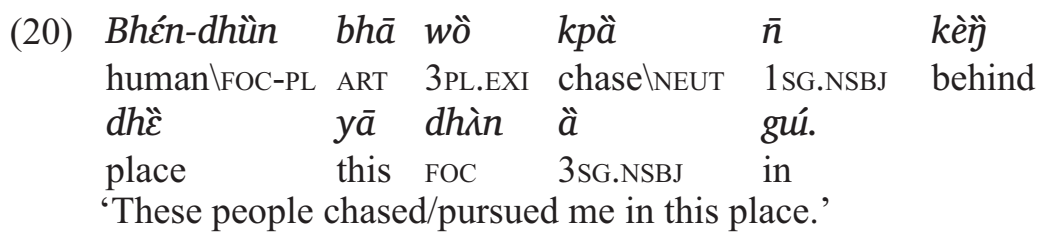


3) The pragmatic status of the patient or patient-like argument. If that argument has a definite article (bhä or dh̀े)) or a demonstrative determiner, the perfect/resultative reading of the neutral aspect construction turns out to be the most likely (or even the only one possible), cf. (24-25).

$\begin{array}{llllll}\text { Tö-dhín-dhün } & b h \bar{a} & \text { wò } & \text { pèn } & \bar{n} & \text { yăan. } \\ \text { chicken-child-PL } & \text { ART } & \text { 3PL.EXI } & \text { scatter|NEUT } & \text { 1 SG.NSBJ } & \text { before }\end{array}$
'The chickens have scattered before me.'
a. $Y \ddot{r}$
kü $y \bar{a}$
à
gbän
$\bar{\gamma}$
3SG.EXI hoe
this
3SG.NSBJ
insert
REFL.SG
gวั
gúu $\bar{\gamma}$ $d \bar{n} \quad d h \ddot{\varepsilon}$.
in REFL.SG father for
'He has hafted this hoe for his father.'

If the argument has an inferior referential status, a habitual or progressive interpretation is more probable. Interestingly, in some cases, the neutral aspect construction with the perfect/resultative meaning differs from the perfect construction by the fact that in the latter, the direct object cannot be provided with a demonstrative determiner. $\mathrm{Cf}$. the incorrectness of (25b) and admissibility of (25c), where the direct object is indefinite (and it is assumed that the hoe is out of sight of the people participating in of the conversation).

$$
\begin{aligned}
& \begin{array}{llllllll}
\text { b. *Yà kă } & \text { ya } & \text { a } & \text { gbăn } & \bar{\gamma} & \text { gò } & \text { gú... } \\
\text { 3SG.PRF hoe } & \text { this } & \text { 3SG.NSBJ } & \text { insert } & \text { REFL.SG } & \text { head } & \text { in }
\end{array} \\
& \text { c. }{ }^{\mathrm{OK}} Y a ̀ \text { kü } \text { gbàn } \bar{\gamma} \quad \text { gò gú... } \\
& \text { 3SG.PRF hoe insert REFL.SG head in } \\
& \text { 'He has hafted a hoe...' }
\end{aligned}
$$

In general, the perfect construction is perceived as a "stronger" perfect, and the connection of its action with the moment of speech as more vivid. Let us consider the following examples.
(26) a
dhà
$\bar{\gamma}$
kāà ká.
3SG.EXI savelNEUT REFL.SG hair with
'He has been saved by a miracle.' 


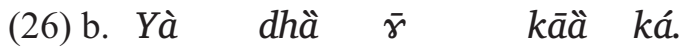 \\ 3SG.PRF save REFL.SG hair with \\ 'He has been saved by a miracle.'}

Both phrases express perfect meaning (actual past), but in (26b) it is presumed that the action has just taken place, most probably before the eyes of those participating in the conversation. ${ }^{15}$

The grammatical meanings of the resultative construction and the neutral aspect construction in its resultative reading differ in a similar way.

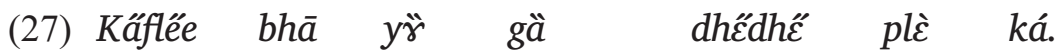
coffee ART 3sG.EXI drylNeUT hour two with 'The coffee (harvested grains) has dried in two hours.' (and now it is only just dry)

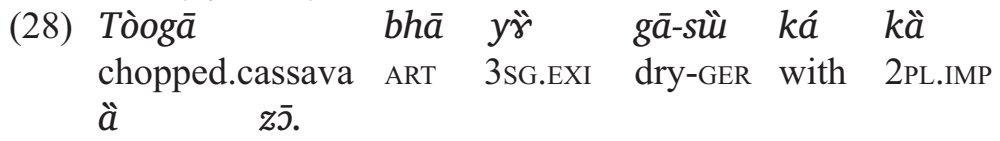

3SG.NSBJ pound

'The chopped cassava is (already) dry, pound it.'

In (27) the state (resulting from the action of the verb) is percieved as highly actual; in (28), it is less so.

Here again, the abovementioned factors involved in the realization of the perfect/resultative meaning do not constitute strict rules, but rather general trends. So, in (29), although the direct object is devoid of the article and other determiners, both resultative and progressive readings are possible.
(29) Tìa $y \ddot{\gamma} \quad k w \tilde{\varepsilon} \varepsilon$ tà
kwànbhên dhìn à
gò.
Tia 3sG.EXI door shutlNeUT thief FOC 3sG.NSBJ for
a. 'Tia has shut the door on thieves.'
b. 'Tia shuts the door on thieves.' (habitual)

${ }^{15}$ For (26a), a "historical" reading is also possible: 'He was saved by a miracle' (in the remote past). 
On the other hand, the perfect/resultative meaning proves to be inaccessible for a considerable number of verbs, although their semantics does not seem incompatible with it, e.g.: kún 'catch', bhînn 'swallow', bhūn 'drink', pìaa 'grill', and many others. Presumably this restriction is lexical in nature.

\subsection{Completive (punctive) meaning}

The availability of the completive meaning has been systematically checked in the following contexts.

1) 'The action took place/was performed during timespan $X$ '.

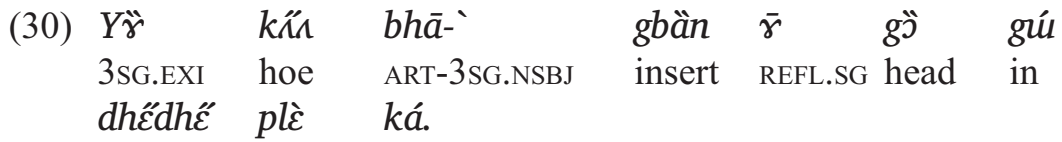

hour two with

'He hafted the hoe in two hours.'

2) 'The action took place/was performed at time $X$ '.

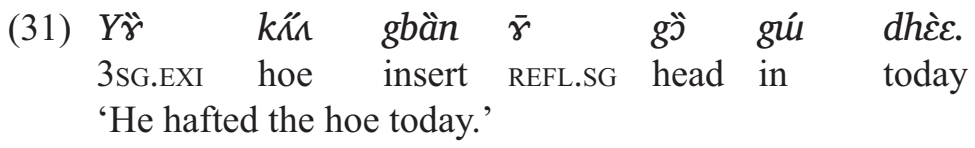

3) 'The action took place/was performed while...' (the adverbial is expressed by a temporal subordinate clause).

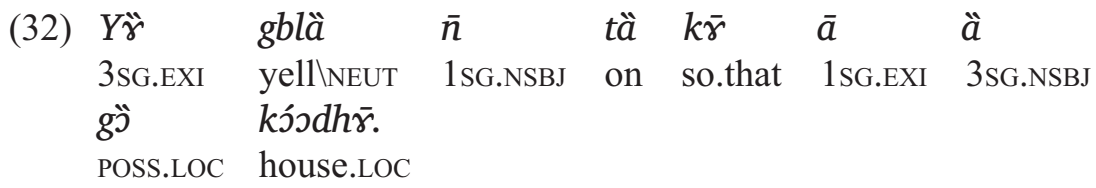

'He shouted at me while I was in his house.'

The first context is diagnostic for the distinction between the completive and the perdurative meanings; the second and the third ones are prototypical completive contexts.

It emerges that the perfect, resultative and completive meanings of the neutral aspect construction are not clearly delimited in Eastern Dan. 
In fact, we have a kind of perfective continuum, similar to that served by the Russian perfective aspect, which may seem strange given that specialized perfect and resultative constructions are also attested. The presence of an adverbial designating a temporal point in the past is not sufficient to reject the perfect/resultative reading of the neutral aspect construction; presumably, the main factor is extralinguistic knowledge about the most typical ways in which events can occur:

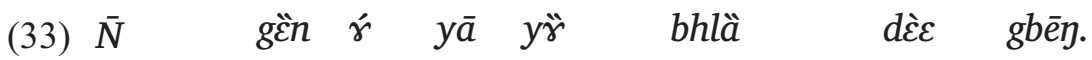
1SG.NSBJ leg REL this 3sG.EXI swell/NEUT today night 'This leg of mine has swollen overnight.' (and the swelling is still there)

(34)

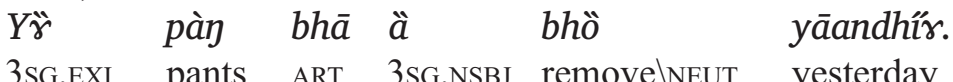

'He put these pants on yesterday.' (and he is still wearing them)

As we can see, having atelic semantics does not prohibit a verb from allowing completive meaning in the neutral aspect construction; in this case, a limitative reading is realized.

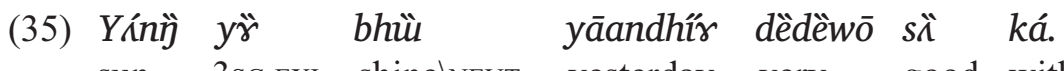
sun 3SG.EXI shinelNEUT yesterday very good with 'Yesterday, the sun shone well.' (and before that, it did not appear much)

(36) Dhín

$b h \bar{a} \quad y \ddot{\gamma}$

dhì̀ dèc gbē̃

child $\backslash F O C$ ART 3sG.EXI moan\NEUT today night

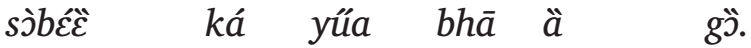

seriousness with illness ART 3SG.NSBJ for

'Because of this illness, the child moaned loudly last night.'

\section{Neutral aspect and Aktionsarten}

A method has been developed for the typologically-oriented identification of verbal Aktionsarten which requires taking into account those grammatical markers which represent universal categorial types 
(Tatevosov 2002; Tatevosov 2005: 119-121). ${ }^{16}$ According to this method, firstly, not a given verb as a whole but only some of its grammatical forms should be considered; secondly, in each language under study, only two grammatical markers should be taken into account: the perfective/past and the progressive/imperfective/present. ${ }^{17}$ The second requirement is a logical corollary of the first: the TAM systems of different languages may be very rich, and establishing the actional characteristics of each verb in each TAM form would be an immense task; besides, performing such comprehensive studies would render incomparable the results obtained for different languages. If only two grammatical forms (the most widespread and basic ones) are selected, the typologist's task becomes manageable.

However, an attempt to apply this method, oriented to predominantly binary TAM systems, to Eastern Dan, brings us to an impasse. In this language, we have a perfect, a resultative, a progressive (more precisely a durative; however, this nuance can be ignored in this context); meanwhile, the existence of the neutral aspect does not allow us to consider the TAM system as binary. The dominant is not an opposition between perfective and imperfective (or past and present), but an opposition between the neutral aspect, occupying the central part of the system, and all the other categories, which are shifted to the periphery.

And yet, the situation does not look hopeless. Tatevosov's requirement can be reformulated in such a way as to state that we should analyze the actional characteristics of those verbal forms which form the center of the TAM-system. In this case, we can limit ourselves to an analysis of the actional characteristics of verbs in neutral aspect.

All the meanings of the neutral aspect construction analyzed in section 4 can be placed in three groups: (1) habitual, stative; (2) progressive, imperfect; (3) perfect, resultative, completive. The first group represents the "default meanings of presence" (Bybee, Perkins \& Pagliuca 1994:

${ }^{16}$ For a critique of this approach, see (Plungian 2011).

${ }^{17}$ In fact, Tatevosov's presumption is very close to Stassen's (1997: 267) “verbal core system" mentioned in footnote 9 . 
152), and its variability can be explained by the lexical semantics of the verbs involved; it can be lumped together with the second group into a "present-imperfective block". The third group represents a "past-perfective block". Therefore, the opposition between two basic forms typical of "binary" systems, corresponds in Eastern Dan to an opposition within the neutral aspect distinguished by context (although sometimes left underdistinguished, as in examples 6-7).

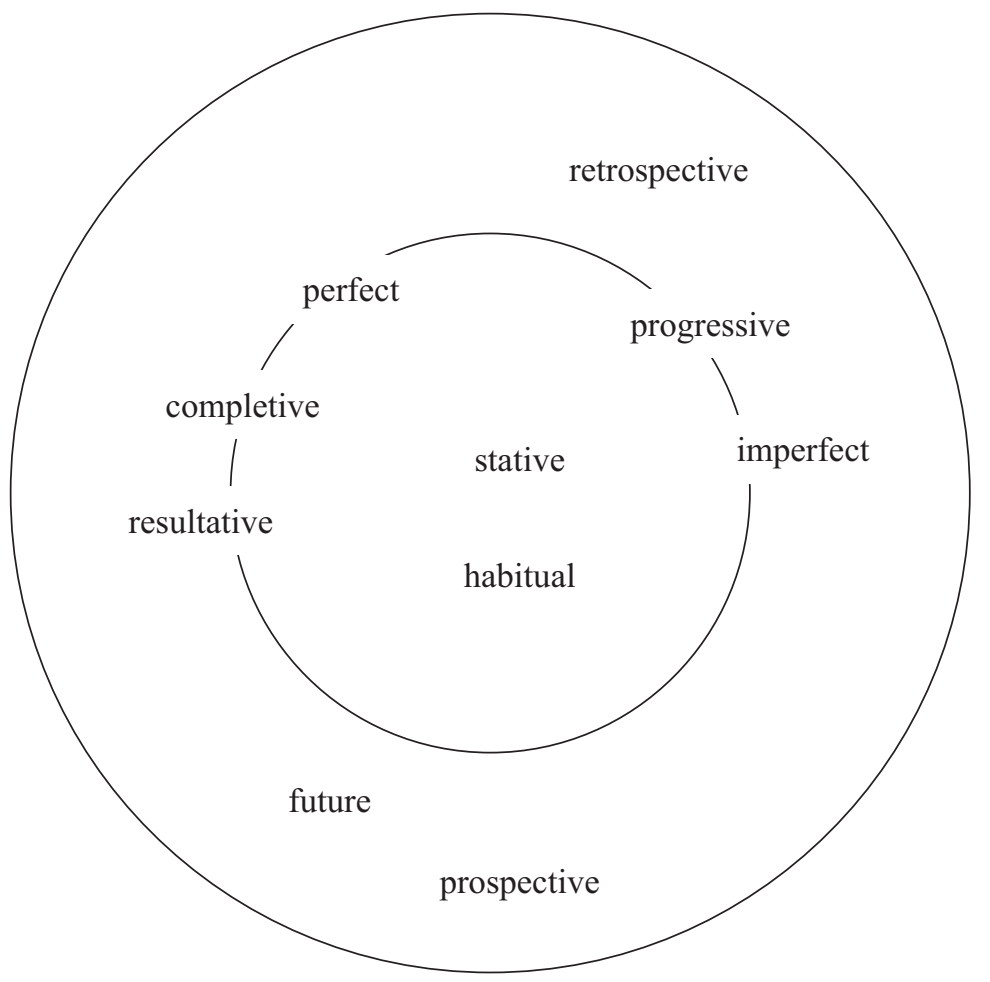

Figure 1. A schematic representation of aspectual system of Eastern Dan.

The aspectual system of Eastern Dan can be represented as two spheres, one being embedded within the other (Figure 1). The inner sphere represents the neutral aspect, and the outer one all the other aspectual 
constructions found in the language. The habitual and the stative can be expressed only by the neutral aspect construction, and the meanings of future and prospective only by specialized constructions (and not by the neutral aspect construction). All other aspectual meanings can be expressed both by the neutral aspect and by specialized constructions. However, in the former case, their aspectual semantics appears somehow dimmed, it is not very clearly separated from other meanings.

\section{Neutral aspect or habitual?}

Another question concerning the construction in question can be formulated as follows: if habitual is, to some extent, its central meaning (in any case, it is the only meaning which turns out to be available for practically all verbs in the neutral aspect construction), might it be more expedient to consider this construction as inherently habitual, in which case all the other aspectual meanings could be regarded as contextconditioned deviations? If so, the perfect and durative constructions could be regarded as central to the Eastern Dan TAM system. ${ }^{18}$

This interpretation may seem tempting, but it comes up against some serious objections.

Firstly, any explanation of non-habitual meanings of the neutral aspect construction in terms of contextual influence cannot accommodate the fact that both habitual and non-habitual readings may be possible in one and the same context, cf. (7).

Secondly, it is not rare in the languages of the world to find a specialized form for the habitual, but, to my knowledge, it is rather unusual for the habitual to have such considerable variability in its semantics as is seen in Eastern Dan. In other words, if we decide to consider the neutral aspect construction as "habitual", we will be obliged to recognize that it is a rather untypical habitual, and to explain the "non-habitual

${ }^{18}$ This interpretation was suggested by Victor Khrakovsky during discussion at the seminar of the Department of typology of the Institute for Linguistic Studies RAS in October 2009. 
meanings of the habitual" at length. To my mind, in this situation the term "neutral aspect" is preferable to "habitual".

Thirdly, as mentioned by Östen Dahl, “... there is a limited set of crosslinguistic gram types, and a limited set of points in semantic space from which tense-aspect markings can arise and spread. $\langle\ldots\rangle$ it so happens that generics occupy a region of semantic space that is not close to any of the points of origin of tense-aspect grams" (Dahl 1995: 146). In other words, from the viewpoint of the typology of evolution of grammatical semantics, habitual is an arrival rather than a departure point for evolutionary itineraries. If we recognize that diachronically the habitual meaning of the Eastern Dan neutral aspect construction is not primary, it seems unnatural to regard it as basic in the analysis of synchronic polysemy.

The fact that the habitual meaning in the neutral aspect construction is accessible to practically all verbs in Eastern Dan (with the exception of stative verbs), while other aspectual meanings are considerably restricted, can be explained in terms of the relative independence of the habitual meaning from the Aktionsart of a verb; in other words, it turns out to be compatible with a wide range of verbal Aktionsarten.

\section{On the origin of the neutral aspect construction}

The presence of the existential series of predicative markers (more precisely, bifunctional auxiliaries) testifies to the originally non-verbal character of this construction. The grammatical $\mathrm{xL}$ tone on the verb may go back to an infinitive suffix (loss of segmental elements alongside retention of their tones is quite typical of Mande languages). In (Vydrin 2012: 616, 620-621) it was suggested that the existential Aux series may result from the fusion of the subject pronouns with the auxiliary * $k E$ (going back, most probably, to the verb * $k \dot{\varepsilon}$ 'do; become'), and the verbal suffix could be hypothetically reconstructed as *-6ä or *-6â̆. This suffix uncontroversially goes back to a superessive postposition; non-finite verbal forms with reflexes of this suffix are broadly represented in the South Mande languages and in other Mande groups. 
The evolution of this construction could have followed a model which is well attested both cross-linguistically (Bybee, Perkins \& Pagliuca 1994: 275-279; Haspelmath 1998) and in Mande languages in particular (Tröbs 2009) "non-verbal locational construction with a verbal noun $\rightarrow$ progressive $\rightarrow$ durative $\rightarrow$ imperfective/habitual". This model explains the imperfective aspectual meanings (progressive, stative, habitual), but not the perfective part of the semantic range seen here. For perfective constructions, the most typical origin in Mande languages is from resultative participles.

A realistic explanation of the combination of perfective and imperfective meanings in a single construction can be found in Östen Dahl's reasoning with regard to the homonymy/polysemy of the generic, progressive and narrative in Afrikaans and, on the other hand, of the generic, past and narrative in Thai: “... the generic contexts will tend to share the unmarked expression with whatever other types of sentences happen to be unmarked in the system. $<\ldots>$ this should not be taken primarily as a sign of a close semantic relation between generics and narratives - rather, the lack of marking should be explained separately for each case" (Dahl 1995: 416). If the neutral aspect construction in Eastern Dan is the "minimally marked" one (and there is no formally unmarked construction in the system), the accumulation of different aspectual meanings may result from mere coincidence. For the habitual meaning, the least marked semantically, the neutral aspect construction is basic (it is the only way to express this meaning), and the other meanings are expressed by this construction when a strong context is available or when explicit expression of these meanings is not obligatory.

\section{Acknowledgements}

This work is supported by a public grant overseen by the French National Research Agency (ANR) as part of the program "Investissements d'Avenir" (reference: ANR-10-LABX-0083).

I would like to express my gratitude to the late Kességbeu Mongnan (Alphonse), my principal consultant for this study. This paper has benefited from numerous comments from members of the field trips to Côte d'Ivoire 
and Guinea (Nadezhda Makeeva, Elena Perekhvalskaya, Maria Konoshenko and others), and also participants of the seminar on typology of the Institute for Linguistic Studies in St. Petersburg (Victor Khrakovsky, Sergey Say, Dmitry Gerasimov), and other colleagues who read preliminary versions of my paper and made comments, as well as anonymous reviewers.

\section{Abbreviations}

$$
1 / 2 / 3-1 / 2 / 3 \text { person }
$$

Adj - adjective

ART - definite article

Aux - auxiliary

CMM - common case

COM - comitative case

DIM - diminutive suffix

DUR - durative

EXCL -1 person exclusive plural pronoun/auxiliairy

EXI - existential series of auxiliaries

FOC - focalization particle

or grammatical high tone

on certain focalized nouns

GER - gerundive suffix

$\mathrm{H}$ - high tone

IMP - imperative series of auxiliairies

INF - infinitive marker (extralow tone

suffixed to the verb stem)

IPFV - imperfective

JNT - conjoint series of auxiliairies;

tonal modification on the verbal

stem in the conjoint construction

$\mathrm{L}$ - low tone

LOC - locative case
$\mathrm{M}$ - middle tone

NEG - negative

NEUT - neutral aspect marker (extra-

low tone on the verbal stem)

$\mathrm{NP}$ - noun phrase

NSBJ - non-subject pronominal

series

$\mathrm{O}$ - direct object

$\mathrm{PFV}$ - perfective

PL - plural

POSS - possessive marker

PRF - perfect; perfect series

of auxiliaries

$\mathrm{PROH}$ - prohibitive series

of auxiliairies

PROS - prospective series

of auxiliairies

PST - past

RECP - reciprocal pronoun

REFL - reflexive pronoun

REL - relativization marker

RETR - retrospective operator

S - subject

SBJV - subjunctive series

of auxiliairies 
SG - singular

TAM - tense-aspect-mood

$\mathrm{V}-$ verb
$\mathrm{X}$ - oblique

$\mathrm{xH}$ - extra-high tone

$\mathrm{xL}$ - extra-low tone

\section{References}

Apresjan, Jury (Апресян, Юрий Д.). 2005. О Moskovskoj semantičeskoj škole (О Московской семантической школе) [About the semantic school of Moscow]. Voporsy jazykoznanija 1. 3-30.

Bybee, Joan \& Perkins, Revere \& Pagliuca, William. 1994. The evolution of grammar: Tense, aspect and modality in the languages of the world. Chicago: University of Chicago Press.

Dahl, Östen. 1995. The marking of the episodic/generic distinction in tenseaspect systems. In Carlson, Greg N. \& Pelletier, Francis Jeffry (eds.), The generic book, 412-425. Chicago: University of Chicago Press.

Haspelmath, Martin. 1998. The semantic development of old presents: New futures and subjunctives without grammaticalization. Diachronica 15(1). 29-62.

Makeeva, Nadezhda (Макеева, Надежда). 2010. Soprjažennye konstrukcii v jazyke kla-dan (Сопряжённые конструкции в языке кла-дан) [The conjoint constructions in Kla-Dan]. In Vinogradov, Viktor (ed.), Osnovy afrikanskogo jazykoznanija. Sintaksis imennyx i glagol'nyx grupp (Ocновы африканского языкознания. Синтаксис именных и глагольных групп) [Foundations of African linguistics: Syntax of noun and verb phrases], 401-412. Moscow: Academia.

Makeeva, Nadezda. 2018. Marques rétrospectives en kla-dan. Mandenkan 60. 123-147.

Plungian, Vladimir (Плунгян, Владимир А.). 2011. Vvedenije v grammatičeskuju semantiku: grammatičeskie značenija i grammatičeskie sistemy jazykov mira (Введение в грамматическую семантику: грамматические значения и грамматические системы языков мира) [Introduction into grammatical semantics: Grammatical meanings and grammatical systems of the world's languages]. Moscow: Rossijskij gosudarstvennyj gumanitarnyj universitet.

Stassen, Leon. 1997. Intransitive predication (Oxford Studies in Typology and Linguistic Theory). Oxford: Clarendon Press. 
Tatevosov, Sergej. 2002. The parameter of actionality. Linguistic Typology 6(3). 317-401.

Tatevosov, Sergej (Татевосов, Сергей Г.). 2005. Akcional'nost': tipologija i teorija (Акциональность: типология и теория) [Actionality: typology and theory]. Voporsy jazykoznanija 1. 108-141.

Tröbs, Holger. 2009. Sprachtypologie, TAM-Systeme und historische Syntax im Manding (West-Mande) (Mande Languages and Linguistics / Langues et Linguistique Mandé 8). Köln: Rüdiger Köppe Verlag.

Vydrin, Valentin (Выдрин, Валентин Ф.). 2006. Ličnye mestoimenija v južnyx jazykax mande (Личные местоимения в южных языках манде) [Personal pronouns in Southern Mande languages]. Acta Linguistica Petropolitana. Trudy Instituta lingvističeskix issledovanij RAN (Acta Linguistica Petropolitana. Труды Института лингвистических исследований РАН) [Acta Linguistica Petropolitana. Transaction of the Institute for linguistic studies RAS] 2(2). 327-413. https://alp.iling.spb.ru/ static/alp_II_2.pdf. (Special issue: Mandeica Petropolitana.)

Vydrin, Valentin (Выдрин, Валентин Ф.). 2012. Aspektual'nyje sistemy južnyx mande $\mathrm{v}$ diaxroničeskoj perspektive (Аспектуальные системы южных манде в диахронической перспективе) [Aspectual systems of Southern Mande languages in diachronic perspective]. Acta Linguistica Petropolitana. Trudy Instituta lingvističeskix issledovanij RAN (Acta Linguistica Petropolitana. Труды Института лингвистических исследований РАН) [Acta Linguistica Petropolitana. Transaction of the Institute for linguistic studies RAS] 8(2). 566-647. St. Petersburg: Nauka. (Special issue: Typology of aspectual systems and categories.)

Vydrin, Valentin (Выдрин, Валентин Ф.). 2017. Dan jazyk (Дан язык) [Dan]. In Vydrin, Valentin \& Mazurova, Julia \& Kibrik, Andrej \& Markus, Elena (eds.), Jazyki mira: Jazyki mande (Языки мира: Языки манде) [Languages of the world: Mande languages], 469-583. St. Petersburg: Nestor-Istorija.

Vydrine, Valentin \& Kességbeu, Mongnan Alphonse. 2008. Dictionnaire Dan-Français (dan de l'Est) avec une esquisse de grammaire du dan de l'Est et un index français-dan. St. Petersburg: Nestor-Istorija. http:// halshs.archives-ouvertes.fr/halshs-00715560

Received 15.07.2019. Received in revised form 26.11.2019. Accepted 27.11.2019 